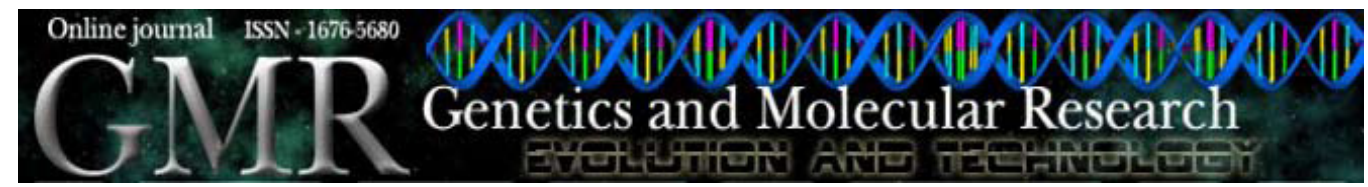

Short Communication

\title{
Confirmation of cross-fertilization using molecular markers in ornamental passion flower hybrids
}

\author{
L.D.H.C.S. Conceição ${ }^{1}$, G.O. Belo ${ }^{2}$, M.M. Souza ${ }^{2}$, S.F. Santos², \\ C.B.M. Cerqueira-Silva ${ }^{3}$ and R.X. Corrêa ${ }^{2}$ \\ ${ }^{1}$ Embrapa Cerrados, Planaltina, DF, Brasil \\ ${ }^{2}$ Departamento de Ciências Biológicas, \\ Universidade Estadual de Santa Cruz, Ilhéus, BA, Brasil \\ ${ }^{3}$ Departamento de Estudos Básicos e Instrumentais, \\ Universidade Estadual do Sudoeste da Bahia, Itapetinga, BA, Brasil \\ Corresponding author: M.M. Souza \\ E-mail: souzamagg@yahoo.com.br
}

Genet. Mol. Res. 10 (1): 47-52 (2011)

Received November 27, 2010

Accepted December 23, 2010

Published January 11, 2011

DOI 10.4238/vol10-1gmr894

ABSTRACT. Several interspecific Passiflora hybrids are produced in
the northern hemisphere for the ornamental plant market. In Brazil,
production of passion flower hybrids is limited to the introgression
of genes into the main cultivated species, yellow passion fruit, to
be used as rootstocks. Confirmation of hybridization in the initial
developmental stage is important for breeding perennial and sub-
perennial plants, such as passion flowers, reducing time and costs in
plant stock maintenance. In order to obtain $\mathrm{F}_{1}$ hybrids with ornamental
potential, four species of Passiflora (P. alata, P. gardneri, P. gibertii,
and P. watsoniana) from the Active Germplasm Bank at UESC
were hybridized. Flower buds, in pre-anthesis, of the genitors were
previously protected, and the female buds were emasculated. To
confirm hybridization, the genomic DNA of the genitor species and
the supposed hybrids was extracted and RAPD primers were used 
to obtain molecular markers and select passion flower interspecific hybrids. Eight primers were used to confirm hybrids derived from $P$. gardneri with $P$. alata, $P$. watsoniana with $P$. alata, $P$. watsoniana with $P$. gardneri, and $P$. gardneri with $P$. gibertii; $75,50,45$, and $46 \%$ of the informative bands, respectively, confirmed the hybrid nature of these plants. The RAPD technique was effective in the early identification of hybrids; this will be useful for development of hybrid Passiflora progeny.

Key words: Passiflora L.; Interspecific hybridization; RAPD; Paternity test

\section{INTRODUCTION}

Hybridizations between species of the genus Passiflora have been carried out in North American and European countries to create and trade several hybrids in the ornamental plant market (Vanderplank, 2000; Ulmer and MacDougal, 2004). Due to the aesthetic attributes of exotic flowers and leaves, and to the great inter- and intraspecific variability, wild passion flowers have been used to decorate gardens and greenhouses since their introduction in the Old World, around 1625 (Ulmer and MacDougal, 2004; Peixoto, 2005). Hybrid passion flowers were first reported in 1819, when Thomas Milne crossed P. racemosa Brot. x P. caerulea L. and produced the hybrid P. violacea (Vanderplank, 2000). In the beginning of the 20th century, there was a considerable increase in hybrid production with ornamental potential, including $P$. 'Amethyst' Vanderplank (unknown genitors); $P$. 'Asterix' Vecchia ( $P$. 'Barbora' x $P$. caerulea 'Constance Eliott'); $P$. 'Colet' Sevcik ( $P$. racemosa $\mathrm{x} P$. naviculata); $P$. 'Lady Margaret' Skimina ( $P$. coccinea $\mathrm{x}$ $P$. caerulea 'Constance Eliott') (Vanderplank, 2002). There are more than 600 registered hybrids in the International Passiflora Society (www.passionflow.co.uk/reg.htm). The largest production center of hybrids is in Germany, controlled by the breeder Dr. Roland Fischer, who bases his work on the induction of polyploidy in selected plants for cultivation in vases (Peixoto, 2005).

In Brazil, the potential of passion flowers as ornamental plants is almost non-explored. In 2007, the first ornamental cultivars of passion flower were released: Roseflora $\left(\mathrm{F}_{1}\right.$ P. coccinea Aubl. x P. setacea DC. x P. setacea DC.), Rubiflora ( $\mathrm{F}_{1}$ P. coccinea Aubl. $\mathrm{x}$ $P$. setacea DC. x P. coccinea Aubl.) and Estrela do Cerrado (P. coccinea Aubl. x P. setacea DC.) (Faleiro et al., 2009). Hybrids have also been produced in Brazil' northeast region for ornamental use, including $P$. 'Alva', $P$. 'Priscilla' and $P$. 'Aninha' (Santos, 2008), originating from the crossing of $P$. palmeri var. lanceolata $\times$ P. foetida var. foetida. The sustainable use of biodiversity and genetic variability in the genus Passiflora may offer a diversification alternative for agrobusiness or family agriculture (Abreu et al., 2009).

The use of molecular techniques provides a fast and accurate assessment of paternity at relatively low cost. Random amplified polymorphic DNA (RAPD) markers have been successfully used to confirm hybrids in cross-fertilization (Junqueira et al., 2008). Confirmation strategy based on DNA eliminates the possibility of developing double haploids (Nimura et al., 2003) and of contamination (Faleiro et al., 2003; Junqueira et al., 2008). Moreover, the confirmation of hybrid plants in the initial development stage is important for reducing time and costs in the maintenance of the plants. Therefore, in addition to the time gain and savings of resources from the use of RAPD markers, higher efficiency and dependability in hybrid confirmation may lead to better results for breeding programs. This study aimed at confirming the hybrid nature 
of plants originating from crossings of passion flower wild species, through the use of RAPD markers, focusing on the selection of genotypes with ornamental potential.

\section{MATERIAL AND METHODS}

The study was carried out with the species $P$. alata Curtis, $P$. gardneri Mast., P. gibertii N.E. Brow, and P. watsoniana Mast. The plants were kept in the Bank of Active Germplasm at UESC (BAG-Passifloras), located at the campus of Universidade Estadual de Santa Cruz (UESC), Ilhéus, Bahia, Brazil (39 $10^{\circ} \mathrm{W}, 14^{\circ} 39^{\prime} \mathrm{S}$; alt. $78 \mathrm{~m}$ ). For the hybridization procedure, the flower buds were protected with paper bags. The flowers were emasculated, pollinated and protected again. Between 40 and 60 days after the pollination, the fruits were collected. The seeds were washed, dried at room temperature and stored in paper bags at $+5^{\circ} \mathrm{C}$. For germination, the seeds were treated in sodium hypochlorite (2.5\% of active chloride) for 2 min and rinsed five times. The seeds were scarified with partial removal of the tegument and afterward placed on filter paper (three layers); they were watered daily with a solution containing 100 $\mathrm{mg} / \mathrm{L}$ gibberellic acid (Ferreira et al., 2005). Around 20 days after germination, the seedlings were transferred to polystyrene trays containing black soil substrate until they reached the proper stage for transplanting.

DNA was extracted from seedlings between 40 and 60 days after germination and used for amplifications by the polymerase chain reaction (PCR). The DNA extraction method used was that described by Doyle and Doyle (1990). The amplification reactions were carried out in duplicate using a total volume of $25 \mu \mathrm{L}$ containing $10 \mathrm{mM}$ Tris- $\mathrm{HCl}, \mathrm{pH} 8.3,2 \mathrm{mM} \mathrm{MgCl}, 100$ $\mu \mathrm{M}$ of each desoxyribonucleotide (dATP, dTTP, dGTP, and dCTP), $0.4 \mu \mathrm{M}$ primer, $1 \mathrm{U}$ Taq polymerase and around 30 ng DNA. Four to eight RAPD primers were tested, which were from an Operon kit and from the University of British Columbia (Table 1). In each PCR, DNA samples of male and female genitors were used, in addition to one sample of each hybrid plant per crossing. The amplifications were carried out in a thermal cycler programmed for 40 cycles ( $1 \mathrm{~min}$ at $94^{\circ} \mathrm{C}, 1 \mathrm{~min}$ at $32^{\circ} \mathrm{C}$ and $2 \mathrm{~min}$ at $72^{\circ} \mathrm{C}$ ). After 40 cycles, a final extension phase of $7 \mathrm{~min}$ at $72^{\circ} \mathrm{C}$ was carried out, and finally, the temperature was reduced to $15^{\circ} \mathrm{C}$. The separation of RAPD fragments was carried out on a $1.6 \%(\mathrm{w} / \mathrm{v})$ agarose gel stained with ethidium bromide, and the results were photodocumented under a UV transilluminator. The molecular markers generated by the different RAPD primers were analyzed in terms of presence or absence of informative bands to confirm cross-fertilization. Only the informative bands with high reproducibility and definition were considered.

\begin{tabular}{ll}
\multicolumn{2}{l}{ Table 1. Sequences of the eight RAPD decamer primers used to confirm cross-fertilization. } \\
\hline Primer & Sequence 5'-3' \\
\hline OPD01 & (5'-ACCGCGAAGG-3') \\
UBC03 & (5'-CCTGGGTCCA-3') \\
UBC04 & (5'-CCTGGGTGGA-3') \\
UBC06 & (5'-GCCCGGTTA-3') \\
UBC11 & (5'-CCGGCCTTAC-3') \\
UBC17 & (5'-CTTACCCGTGC-3') \\
UBC23 & (5'-GTCCACACGG-3') \\
UBC25 & (5'-ACCCCCGCCG-3') \\
\hline Primers from University of British Columbia (UBC) and Operon (OPD).
\end{tabular}

Genetics and Molecular Research 10 (1): 47-52 (2011) 


\section{RESULTS}

From the crossings carried out between Passiflora species, 22, 37, 51, and 31 seedlings were obtained from the following hybridizations $P$. gardneri $v s P$. alata, $P$. watsoniana vs $P$. alata; $P$. watsoniana vs $P$. gardneri, and $P$. gardneri vs $P$. gibertii, respectively. All four crossings had their hybrids confirmed by the presence of at least four informative bands (Figure 1; Table 2). The highest percentage of positive informative bands (present in the hybrids) was obtained in crosses between $P$. gardneri and $P$. alata $(75 \%)$. However, only six were considered to be markers of four primers. We used the largest number of primers in the cross $P$. gardneri vs $P$. gibertii, but only $46 \%$ of the bands were considered to be informative, confirming the cross-fertilization. The crossing between $P$. watsoniana vs P. alata indicates that half of the primers used did not produce informative bands, but four bands did confirm the hybrids.
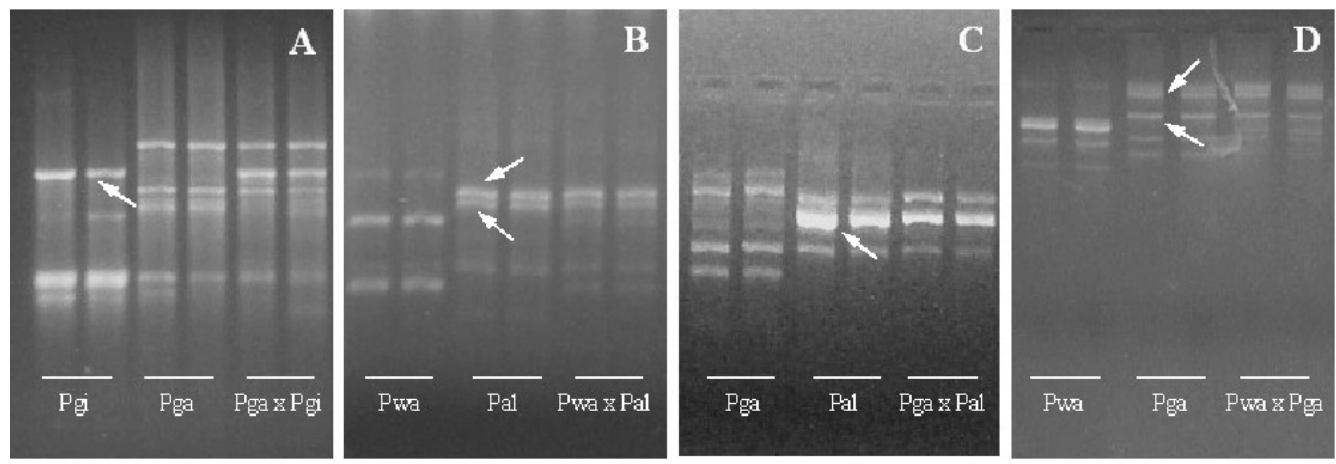

Figure 1. Standard amplification of samples of genomic DNA of the genitors and interspecific hybrids. A. Passiflora gardneri (Pga) vs P. gibertii (Pgi), with UBC23 primer. B. P. watsoniana (Pwa) vs P. alata (Pal) with UBC11 primer. C. $P$. gardneri vs $P$. alata with OPD01 primer. D. P. watsoniana vs P. gardneri with UBC04 primer. Arrows indicate informative bands.

Table 2. Number of RAPD informative bands amplified from DNA of the male genitor and the interspecific hybrids of passion flowers using eight primers.

\begin{tabular}{lcccc}
\hline Primer & \multicolumn{3}{c}{ Crossings } \\
\cline { 2 - 5 } & P. gardneri vs P. gibertii & P. gardneri vs P. alata & P. watsoniana vs P. alata & P. watsoniana vs P. gardneri \\
\hline UBC03 & 1 & - & 0 & - \\
UBC04 & 1 & 2 & 4 & 4 \\
UBC06 & 3 & 1 & - & - \\
UBC11 & 4 & - & 2 & - \\
UBC17 & 0 & - & 2 & - \\
UBC23 & 2 & - & 0 & 4 \\
UBC25 & 2 & 1 & 0 & 0 \\
OPD01 & - & 2 & - & 3 \\
Bands & 13 & 6 & 8 & 11 \\
Bands & 6 & 4 & 4 & 5 \\
\% & 46 & 75 & 50 & 45 \\
\hline
\end{tabular}

Bands + confirm hybrids. 


\section{DISCUSSION}

The presence of one or more informative bands with a small number of primers can provide the confirmation of cross-fertilizations (Faleiro et al., 2003). Similar results were obtained in hybrids between $P$. palmeri var. sublanceolata $v s$ P. foetida var. foetida, using almost the same RAPD primers used in this study, and interspecific hybridizations were confirmed (Santos, 2008). The absence of informative bands in some primers may be explained by low reproducibility, weak fragment amplification or even their low monomorphic features among the parents. Junqueira et al. (2008) confirmed 17 interspecific hybrids between Passiflora species, by the presence of informative bands, using RAPD markers. The technique also proved to be efficient in proving that plants obtained from a fruit of Theobroma cacao, after crossing with $T$. grandiflorum, were not obtained by cross-fertilization, but rather by self-fertilization (Faleiro et al., 2003).

The species involved in the crossings show important characteristics for ornamental uses, considering aspects related to florescence and features of flowers and leaves. P. alata has $10-$ to $12-\mathrm{cm}$ shiny pendulous flowers, $10-12 \mathrm{~cm}$ in diameter, with magenta petals and coronal filaments with several shades of red, white and purple (Nunes and Queiroz, 2006). On the other hand, P. watsoniana is smaller than P. alata, which is important for the reduction of such features and selection of indoor plants. The glabrous leaves, with purple abaxial face of $P$. watsoniana, are also attractive in terms of leaves.

Development and growth studies indicate that $P$. gibertii is precocious when compared to $P$. edulis f. flavicarpa and $P$. cincinnata. The precocity of the presence of reproductive organs in $P$. gibertii has already been observed, evident in the main branch and in the secondary branches, compared to other species, at which time, are still in the vegetative phase (Silva et al., 2005a). The time of flower opening for $P$. gibertii is another attractive feature for its use in hybridizations: its flowers open at 11 am and remain open until $2 \mathrm{pm}$ on the following day, totaling up to $18 \mathrm{~h}$ of opening (Silva et al., 2005b).

P. gardneri has flowers that are interesting for decoration, which vary from 6 to 8 $\mathrm{cm}$ in diameter, with violet petals and corona filaments. One important aspect concerning $P$. gardneri is the easy compatibility in interspecific crossings. Attempts to obtain hybrids of $P$. watsoniana and $P$. alata with the species $P$. gibertii failed (data not shown). Thus, indirect crossings would be a possible alternative, aiming at the transfer of features of $P$. gibertii in triple hybrids, involving F1 ( $P$. gardneri vs $P$. gibertii) and the species $P$. watsoniana or $P$. alata.

The RAPD technique is effective in the early identification of hybrids. The selection of individuals in the hybrid progeny, with recombinant traits of the parents involved in crosses, is promising in obtaining new ornamental hybrids.

\section{ACKNOWLEDGMENTS}

Research supported by FAPESB (Fundação de Amparo à Pesquisa do Estado da Bahia), CNPq (Conselho Nacional de Desenvolvimento Científico e Tecnológico) and UESC (Universidade Estadual de Santa Cruz). The authors thank Elisa S.L. Santos for her help in laboratory work. 


\section{REFERENCES}

Abreu PP, Souza MM, Santos EA, Pires MV, et al. (2009). Passion flower hybrids and their use in the ornamental plant market: perspectives for sustainable development with emphasis on Brazil. Euphytica 166: 307-315.

Doyle JJ and Doyle JL (1990). Isolation of plant DNA from fresh tissue. Focus 1: 13-15.

Faleiro FG, Pires JL and Lopes UV (2003). Uso de marcadores moleculares RAPD e microssatélites visando a confirmação da fecundação cruzada entre Theobroma cacao e Theobroma grandiflorum. Agrotropica 15: 41-46.

Faleiro FG, Almeida BC, Sousa PFC, Junqueira NTV, et al. (2009). Obtenção e Análise de Descritores dos Híbridos de Maracujazeiro Ornamental BRS Estrela do Cerrado, BRS Rubiflora e BRS Roseflora. In: $5^{\circ}$ Congresso Brasileiro de Melhoramento de Plantas, CD, Guarapari.

Ferreira G, Oliveira A, Rodrigues JD, Dias GB, et al. (2005). Effect of aril on Passiflora alata seed germination in differents substrates and submitted to previous germinative treatments with gibberellin. Rev. Bras. Frutic. 27: 277-280.

Junqueira KP, Faleiro FG, Junqueira NTV, Bellon G, et al. (2008). Confirmation of interspecific hybrids in passiflora using molecular markers. Rev. Bras. Frutic. 30: 191-196.

Nimura M, Kato J, Mii M and Morioka K (2003). Unilateral compatibility and genotypic difference in crossability in interspecific hybridization between Dianthus caryophyllus L. and Dianthus japonicus Thunb. Theor. Appl. Genet. 106: $1164-1170$.

Nunes TS and Queiroz LP (2006). Flora da Bahia: Passifloraceae. Sitientibus Ser. Cienc. Biol. 6: 194-226.

Peixoto M (2005). Problemas e Perspectivas do Maracujá Ornamental. In: Maracujá: Germoplasma e Melhoramento Genético (Faleiro FG, Junqueira NTV and Braga MF, eds.). Embrapa Cerrados, Planaltina, 456-464.

Santos EA (2008). Melhoramento de Passifloras para Ornamentação Utilizando Passiflora palmeri var. sublanceolata, Passiflora foetida var. foetida e Híbridos F1 Ornamentais: Confirmação via RAPD, Parâmetros Genéticos e Efeitos do Sombreamento. Master's thesis, Universidade Estadual de Santa Cruz (UESC), Ilhéus.

Silva AC, Silva AC, Lucena CC, Almeida FFD, et al. (2005a). Crescimento e Desenvolvimento de Espécies Passifloras. In: IV Reunião Técnica de Pesquisas em Maracujazeiro, 30 de Novembro a 2 de Dezembro, EMBRAPA, Planaltina, 137-142.

Silva AC, Silva AC, Lucena CC, Vasconcellos MAS, et al. (2005b). Dados Preliminares de Biologia Floral de Algumas Espécies de Passifloráceas. In: IV Reunião Técnica de Pesquisas em Maracujazeiro, 30 de Novembro a 2 de Dezembro, EMBRAPA, Planaltina, 137-142.

Ulmer T and MacDougal JM (2004). Passiflora: Passionflowers of the World. Timber Press, Portland.

Vanderplank J (2000). Passion Flowers. The MIT Press, Cambridge.

Vanderplank J (2002). More wonderful cultivars. Passiflora 12: 1-8. 